\title{
INTRODUCTION
}




\section{UNEXPECTED GENERATION}

The CONTEMPORARY POLISH JeWISH milieu provides a unique context for the study of identity construction and cultural representations. Both Polish Jewish culture and Polish Jewish identity remain far from self-evident concepts. Jewish culture in contemporary Poland is not a returning phenomenon. It is a new construct, which very much relies on its past renderings and aspires to be rooted, to be a continuation. It has to be appreciated though that what we are witnessing in post-transition Poland is no Jewish cultural comeback but rather an ongoing struggle to construct an utterly new contemporary Polish Jewish culture. Jewish culture has been part of the Polish landscape for centuries, yet its "reappearance" after 1989 has to be appreciated as an entirely new phenomenon. The emergence of a contemporary Jewish culture in Poland provokes new questions regarding the processes of defining Jewish culture and the processes of defining Jewish identity. Unique patterns of Jewish affiliation and of identity construction, which have surfaced in the Polish context during the past two decades, generate novel analytical categories. The conventional categories of classification of Jews as an ethnic, national, religious, or linguistic minority become largely anachronistic in the context of contemporary Poland. The study of the "particularly Polish" patterns of Jewish identity construction encourages a reassessment of the dominant analytical approaches, as does the study of the "unexpected generation" of Polish Jews. The participants in this study illustrate identities in transition, identities in question, identities in discussion, and hybrid or uncertain identities, and their narratives are set against the backdrop of a unique and dynamic cultural milieu.

In this study, I examine the ways in which young adults in contemporary Poland, who discover or "stumble over" their Jewish roots, give accounts of their experience, their search for forms of Jewish affiliation, their struggle to construct models of being Jewish, and their attempts to legitimize or authenticate their belonging to the Jewish collective. It 
is the objective of this book to pursue an understanding of the processes and patterns involved in the construction of new Polish Jewish identities. These processes are revealed in the activity of narrating identity.

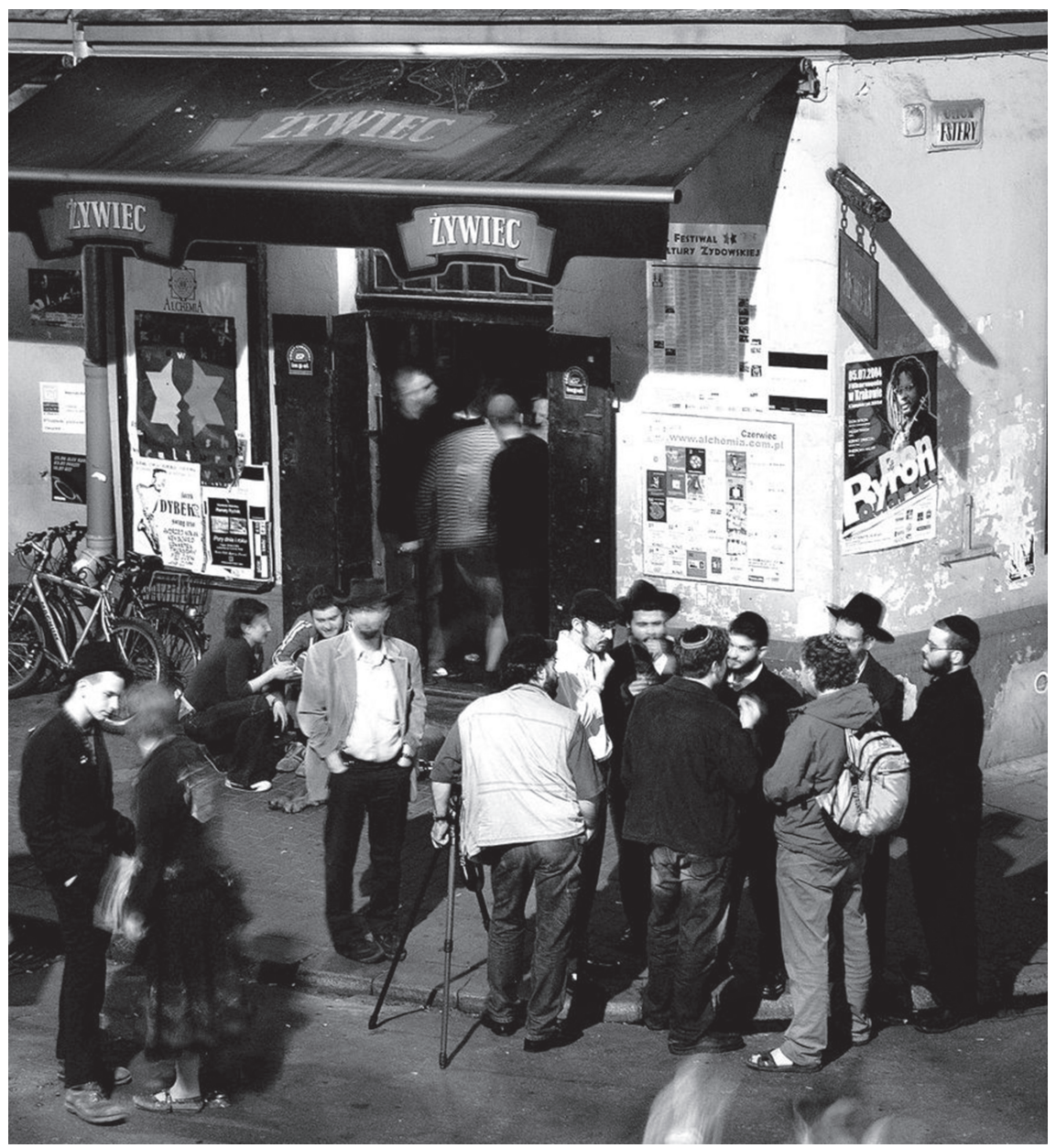

Kazimierz - The Jewish District of Krakow in 2004. 
My research took place between 2001 and 2011. Semi-structured interviews were conducted with fifty young Polish Jewish adults. The conceptual and theoretical frameworks of identity, Jewish identity, ethnicity, conversion, and authenticity served as resources for both the process of data generation, in which I used them as points of reference during the interview, and for data analysis. A comprehensive analysis of the participants' narratives brought about a number of central themes and patterns, which are presented in the results section. I focus on the ways in which young representatives of the third post-Holocaust generation of Jews in Poland narrate their transition into Jewishness and the ensuing process of construction of their Jewish identities.

The individuals I interviewed for this study are young adults who can be considered members of the new generation of Jews in Poland, born in the late 1970s to the early 1990s. The focus of my research was on individuals who learned about their Jewish roots in their teens. Although a number of the people I interviewed claim that they always had an awareness of their Jewish origin, they too only began seeking a form of Jewish affiliation in their teen years. For all the interviewees, the teen years began after the democratic changes which took effect in Poland after the fall of the communist regime in 1989. It is important to emphasize that none of the participants in this study was raised in a Jewish environment; rather, they all grew up in Christian or atheist households. All of the participants in the study represent the demographic group called the 1989 generation (Irwin-Zarecka 1990; Rosenson 1996) or the third post-Holocaust generation of Jews in Poland.

The study focuses on patterns involved in narrating identity. I analyze the ways in which people give accounts of the circumstances, events, decisions, thoughts, and dilemmas which accompany them on their way to a Jewish affiliation. I undertake to show how the words of the representatives of the third generation reveal what processes are involved in assuming a cultural legacy. This requires analyzing the conceptual and evaluative frameworks, which they resort to in the interpretation of their experience and in the construction of personal representations, including the ways ideas about culture and identity are addressed in both descriptive and evaluative terms. Finally, my analysis focuses on how the interviewees locate themselves within the socio-cultural landscape and formulate models of authentication in the context of their developing Jewish affiliations and in the pursuit of a legitimate status 
within the Jewish community. Narrating identity is a work in progress, and consequently, I can merely try to capture and give an account of but a fragment of the story or rather of a number of fragments of a number of stories. Common themes and patterns that emerge in the analysis are exposed here in an attempt to best represent the phenomena taking place in contemporary Poland with regard to construction of Jewishness.

The narrative dimension, which is the primary focus of my analysis, finds itself at the crossroads of the prevalent postulates nurturing contemporary identity debate. In the present volume, I examine the "lay perspectives" (Hampson 1994) which transpire in how young adult Jews in Poland look at identity and ethnicity. Through personal stories, I provide an account of the "lay theories," which implicate references to existing "formal" theoretical frameworks and dominant discourses. These references are revealed in different attempts at conceptualizing identity, that is, Jewish and Polish identity, but also identity in general. They are also manifested in individual responses to the question of authenticity. Furthermore, the particular narratives illustrate rhetorical patterns, which can be interpreted in light of the discourse of ethnic identification, along the tenets of primordialism and circumstantialism.

The concept of conversion provides another important theoretical framework. The notion of conversion holds analytical value as it proves to be an operative means of identifying different individual lay perspectives related to Jewish identity, ethnic belonging, and, most importantly, group boundaries. The idea of conversion is also directly associated with issues of authenticity. Conversion to Judaism is an important notion in the discourse of the participants, and it accounts for one of the key references, which make it possible for us to pinpoint more general approaches to Jewish identity and its boundaries.

In the subsequent parts of the introductory section, I provide the socio-historical context of this study. I then delineate our major theoretical and analytical frameworks. I discuss various approaches to the concept of identity, and I go on to present the relevant theories of ethnicity. With regard to the latter, I focus particularly on the debate on primordialism and circumstantialism. I then provide different conceptualizations of Jewish identity, which reflect different approaches to identity in general. I bring in the notion of conversion, understood not only as a religious process but also as an identity transition. Finally, I 
present an outline of some of the theoretical perspectives on the idea of authenticity as a subject of an ongoing debate in contemporary human sciences. The introductory section is concluded with the research question, as it emerges in light of the presented theory. 


\section{About Me}

And He spoke to you and as He swore to your forefathers, to Abraham, to Isaac, and to Jacob. Not with You alone do I forge this covenant and oath but with whoever is here, standing with us today, before Hashem, your God, and with whoever is not here with us today (Devarim 29:9-14).

ACCORDING TO RASHI, THE prominent Bible commentator, "Whoever is not here" means also to include the generations of Jews who will exist in the future. Rashi's comments are based on the biblical interpretation found in Midrash Tanchuma, Nitzavim 3: "The souls of all Jews were present at the making of the covenant even before their physical bodies were created."

One might say that the stories of the young generation of Polish Jews are precisely the kind of stories that inspire such commentaries, and of course - for some-they validate the mystical message.

Perhaps a midrash like this one is in fact the only way to "explain" why so many representatives of this "unexpected generation" of Polish Jews report being drawn to the Jewishness in them before they had any awareness of it. Indeed, many of these stories of the discovery of Jewish roots, including my personal story, are admittedly-mystical skepticism aside-archetypal of those irrational "pintele yid" kinds of stories. The "pintele yid" is the phrase used to describe that mysterious "Jewish spark" or more literally "the little point of a Jew," as the Yiddish expression has it, which was inscribed at Sinai in every Jewish soul, whether present or not, whether already born or yet to come.

I grew up in a liberal Polish Catholic home. This meant that we generally attended church on holidays and some Sundays, and that my parents always passionately criticized the Catholic establishment. My most vivid childhood memory of church is the memory of how much I hated it. I guess you could say that what I prayed for most was to wake 
up ill every Sunday. Since I was a "good kid," I actually worried that this "allergy" to church meant that there was something wrong with me.

When I was about sixteen years old, I started "becoming Jewish." I read everything I could find in Polish and in English about Jews and Judaism, and I talked about Jews and about Judaism at home and in school. My high school friends started calling me a Jew. Some of the comments were good-humored, others were not. At home, as well as at my grandmother's home, my talking about Jews and inquiring about the family's possible Jewish roots was always surprisingly welcome. It was around the time when I realized that it was not at all common in Poland to be raised thinking that Jews are a wonderful people. I came to believe that if that was all I ever heard from everybody, on both sides of the family, there is likely a Jewish connection there.

My great-great-grandmother on my mother's side was born in Stryj, Poland, which is now in the Ukraine. Her daughter, my greatgrandmother, was born in Hungary, then lived in Tschernovitz (which was then in Romania and is now in the Ukraine) and moved to Poland after the war. I was lucky enough to have known my great-grandmother. She died when I was in my early teens, and my memories of her are scarce but vivid. She was a peculiar tiny lady with a noticeably dark complexion. My mother often recalled curious childhood memories of her grandmother, my great-grandmother. My great-grandfather used to pull odd jokes on her. He would hide in the closet with a large shawl over his head and some sort of box on his forehead. He would wait for his wife to open the closet and sway before her muttering: "Sholem Aleichem, Sholem Aleichem," pretending he was a religious Jew. This would drive my great-grandma crazy; she would chase him around the kitchen with a rolling pin, yelling, "You idiot, it's not funny, what if someone sees you!?"

Everyone else thought it was funny. Everyone else also knew that my great-grandfather was very sympathetic to Jews, and the reason he made these jokes was precisely because they caused such a curiously strong reaction from my great-grandma. It took no less than a few decades before it became clear that the reason my great-grandmother was so sensitive to these jokes was that she was in fact guarding a family secret. I made it my mission to connect the dots. I interviewed other family members and discovered a number of odd rituals and customs my great-grandma used to practice. Nobody knew what they meant, and it was not until 
I studied Judaism that I could actually decipher the meaning behind them. Without going into details, some of the "strange" things my greatgrandmother used to do were keep her milk and meat dishes separate and follow strict rules when baking challah bread, including the laws of hafrashat challah-removing a piece of the dough from the batch, and covering the two challah loaves with a cloth. She had only one elusive answer to any questions her children or grandchildren asked about the obscure rules: "It's just a custom." She knew the customs from her mother-my great-great-grandmother-and in fact we suspect today that perhaps it was my great-great-grandmother who made sure that the family's Jewishness would eventually be successfully obscured. She could not have known that a few generations later I would come along and mess with her plan. After all, Great-Grandma had a point when she used to call me meshuggeneh, which means "crazy" in Yiddish.

During the period when I began confronting my suspicions about a Jewish family link with reality, I decided to look for "real Jews" and see what it was all about. To make a long story short, I ended up volunteering at the Jewish Congregation of Wroclaw, and I soon realized that the young Jews there were no more "real" than I was. We were all in our late teens and early twenties, and we all had a Jewish grandparent, regardless of whether we could find hard or soft evidence of it. We had all been baptized and were now determined to be Jewish and still trying to figure out what it would mean for each and every one of us. Today, over a decade later, it is fair to say that we all still ask ourselves questions about what it means to be Jewish and what is it that makes each of us Jewish, but we no longer question whether we are Jewish or not. We can all now say without hesitation that we are Jewish, and in some sense that is perhaps more identity luxury than many could hope for.

In my early twenties, I ended up immigrating to Israel, where I lived for almost five years. I like to think of Israel as a peculiar identity resort or spa. We-the third generation of post-Holocaust Polish Jews-go to Israel for a few days, weeks, sometimes years, and give our Jewish identities a vacation. In Israel, our Jewish identity is of little importance, and we don't have to represent the lost millions because they are already represented there. We can see what it's like to be Jewish somewhere where it's not such a big deal. Our identity can take a holiday from all the self-questioning. In Israel, whether we drive on the Sabbath or not is not considered vital to Jewish survival. In Israel, the general feeling 
is that everyone is Jewish. We are the majority there, and Jewish life can carry on without us. In Poland, we are the very Jews responsible for Jewish survival. In Israel, we are de facto Poles surrounded by "real" Jews who- unlike us - do not discuss their Jewishness every day.

Despite the difficult politics, I enjoyed living in Israel very much. I became an Israeli citizen, and it was in fact purely circumstantial that I ended up going back to Poland for a while and soon found myself living in New York City - or perhaps somewhat between Poland and New York City. But the truth is that the Israeli experience, my time as a doctoral fellow at the Hebrew University in Jerusalem, having learned Hebrew, and having lived a relatively observant liberal Modern Orthodox life there, were all part of a process of attaining a level of confidence in my Jewish identity I could never have attained otherwise. In Israel, I may have learned more than I would have learned being brought up in a Jewish environment, and in that sense I needed those years to discover what kind of Jew I could or should be. As a largely secular person today, I continue to bewilder many Jews and non-Jews alike with the fact that I continue to perform many Jewish rituals, that I shake the "four species" on the Jewish holiday of Sukkot, that I make kiddush over wine, or that I refuse to work on Shabbat.

My grandmother as well as my parents turned out to be fully sympathetic to my decision to pursue a Jewish affiliation, and to my amazement and pride, my parents chose to declare double nationality-Polish and Jewish - in the recent Polish national census. Interestingly, as soon as I immigrated to Israel, my grandmother on my father's side suddenly decided to mention that her father was in fact Jewish. She never felt the need to share this particular piece of information with my father: "You never asked," she replied when confronted about it. So in the end, I found Jewish roots on both sides of the family, which always makes me wonder just how many Poles there are out there who could find Jewish ancestors if they only started looking. And as such ironies of history like to have it, in 2012, as I was making the final edits to the present book, my father's ninety-two-year-old father surprised him with the following words: "I shall not take to the grave with me the secret that I am a Jew." Unfortunately, my grandfather passed away before we were able to begin to assemble the fragile pieces of his story.

In Poland, many of us will never be able to document our roots, and in that sense, our ancestors have succeeded in disguising their identity. 
Yet, at the same time, we are a living proof of the fact that the identity lives on, against all odds, whether we can prove our Jewishness on paper or not. Ultimately, how much has hard evidence to do with how well we really know who we are?

I have lived in Jerusalem, and I have lived in New York-arguably the two most Jewish places on the planet. And yet, strangely, I never feel more Jewish than I do in Poland; it is against the Polish landscape that my Jewishness is revealed to me most vividly. And it is likely to stay this way. One thing I can say in all certainty after all those years is that although my Jewish identity is forever fluid, as is the nature of all identities in my view, it is by all means and above all my very own.

Our phenomenon - the unexpected appearance of a third postHolocaust generation of Polish Jews-brings about all the fundamental philosophical questions regarding Jewish identity. It illuminates both the perceived "essence" of Jewishness, and its perceived periphery and boundaries. It offers an entirely new perspective on the question of "Who is a Jew?" and questions the seemingly most obvious truths about being Jewish. Suddenly, we have an entire generation of people who individually in some sense account for a polyphony of answers to the eternal questions of "Who is a Jew?" and "What makes a Jew?" and at the same time they question every definitive answer just by being who they are. 


\section{SOcio-Historical CONTEXT}

“By the Time THE Red Army 'liberated’ Warsaw in January 1945, there was nobody and nothing to liberate, except for stray dogs and rats" (Zamoyski 1987, 368). Within months, all of Poland fell prey to the communist regime. "What [. . .] happened in 1944-8 was that the Soviet Union forcibly imposed a Soviet-style communist system on Poland, regardless of the people's wishes or the country's independent interests" (Davies 1984, 3). For forty-four years since the end of World War II, the Polish experience was that of an authoritarian and practically totalitarian state. The nauseating meanders of political affairs in communist Poland fostered subsequent waves of Jewish emigration. The utter inconsistency on the part of the communist government was particularly well reflected in its policy toward Jews, whether official or covert.

Less than 10 percent of the pre-war Polish Jewish population survived the Holocaust. In 1945, some 74,000 Jews, mainly survivors, registered with the Central Committee of Jews in Poland (Polonsky et al. 1996). They were joined by approximately 200,000 Jews who repatriated from the territories of the Soviet Union. Many chose to emigrate immediately. A substantial sector of those who remained in Poland sought new hopes, some of them assuming active roles in the Stalinist regime perceived at the time as a promise of a secular paradise free of all forms of nationalisms and xenophobia, and some following other patterns of assimilation (see Redlich 2011). In the first decade after World War II, the communist government was especially sensitive to the problem of antisemitism, and perceived it as an attribute of rightwing, oppositionist tendencies within society (Cala and Datner-Spiewak 1997). While anti-Jewish assaults persisted, the ruling elite made sure its policy openly condemned manifestations of antisemitism in order to protect its image in foreign public opinion. While Jews continued to leave Poland for Western countries or for Palestine and later Israel, antiJewish overtones became increasingly manifest in the demonstration of society's dissatisfaction with the ruling elite. 
The first serious crisis of the regime came in 1956. Stalin's death in 1953 followed by the mysterious death of the leader of the Polish communist party, Boleslaw Bierut, led to the demise of the Stalinists in Poland. Both the Soviets and the new communist leadership in Poland took the opportunity to express their concerns regarding Jewish "overrepresentation" in the party's ranks. In his de-Stalinization speech of 1956, Nikita Khrushchev made a point of the fact that the Polish communist leadership already had "too many Abramoviches," and although such antisemitic Soviet declarations received no official sanction in Poland at the time, the general anti-Jewish mood was already unquestionable. Along with a national revolt, which was to instill a new, Polish version of socialism, nationalist tendencies began emerging on the part of the authorities as a means of strengthening the image of the new political elite (Irwin-Zarecka 1990; Kersten and Szapiro 1993; Schatz 1991). As a result of growing anti-Jewish sentiments at the time when emigration was again permitted, between 1956 and 1959, approximately fifty thousand Jews left Poland, mostly for Israel (Schatz 1991).

Official antisemitism, which was out of the question in 1956, became a notorious motif in the Polish communist ideology of the 1960 s, reaching its climax in 1968. Israel's victory in the Six-Day War in 1967 triggered the already simmering official anti-Jewish resentments. Accusing Israel of aggression and the reversal of Polish official policy, which was previously supportive of Israel, came along with a parallel change in Soviet policies (Irwin-Zarecka 1990). In Poland, the stereotypes of Jews as communists, Jews as national nihilists, and Jews as a subversive political "fifth column," were now topped with a new one-that of the Jew as Zionist, assuming Israel as his only true homeland. Hence, the Jews were now perceived as traitors to Poland and an obstacle on her glorious way to socialism. Notably, most of the Zionists Poland did have in the late sixties had by that time left for the Land of Israel, and the ideological remains of political Zionism, if at all present, were far from threatening or underhanded in the Polish context. The curious hybrid in the form of nationalist communism gave birth to an antisemitic "mutant," which was used in the power struggle for the creation of a socialist Poland relatively independent of the USSR. This led to a major campaign against all intellectual dissent. Being an essentially anti-liberal and antiJewish campaign, it secured the final disillusionment and once and for all shattered the belief in the emancipating capacity of the communist 
vision (Schatz 1991). The party's cultural policy triggered students' and intellectuals' demonstrations and protests, which the communist party's First Secretary, Wladyslaw Gomulka, was quick to attribute to "instigators" of Jewish origin. Such antisemitism and anti-intellectualism was meant to channel social discontent into popular support (Schatz 1991). Although met with some opposition from the Polish intelligentsia, the government's anti-Jewish policies were nevertheless largely endorsed by the workers and by much of public opinion. Whether convinced communists or not, and whether pursuing some form of Jewish affiliation or complete assimilation, all people of Jewish descent became targets of persecution in March 1968. Among them were even those for whom their Jewishness had hitherto been a mystery. Historians argue that the emigration "encouraged" by the events of March 1968 practically completed the "removal" of Jews from Polish lands (Kersten and Szapiro 1993). Having fulfilled their function as scapegoats in the shifting policies of the government and having been "permitted" to leave (interestingly, all those with at least one Jewish grandparent were automatically "made eligible" for emigration) and stripped of Polish citizenship, they were now to disappear also from Polish public discourse and from Polish national memory, as it was constructed along the lines of the new socialist order.

More than 20,000 Jews were forced to leave Poland as a result of the purge of 1968, leaving between 5,000 and 10,000 Jews in the country (Gebert 1994; Irwin-Zarecka 1990). However, a number of those who found out about their Jewish roots in these malevolent circumstances initiated a process of self-discovery, which proved to be of great significance for the next generation and for the Polish Jewish circumstance at large (Krajewski 2005). The complex history and the consequences of the anti-Zionist campaign remain the subject of debate and research to this day (Grabski et al. 1997; Krajewski 1997, 2005; Melchior 1990; Rosenson 1996).

Perhaps not at all paradoxically, the events of March 1968, being the most overt exposition of post-war government-sponsored antisemitism, evoked contrary tendencies on the part of the political opposition (Ury 2000). Inasmuch as for three decades following the end of the Second World War, Jews were still disappearing from Polish land, as early as in the late 1970s and throughout the 1980s, the "Jewish question" reappeared in public discourse. Significantly, this time it was addressed also from within. To be Jewish or "pro-Jewish" after the March events became 
a way of "defying the authorities" in the maturing struggle for a pluralist democracy (Hoffman 1992; Rosenson 1996). In 1979, the Jewish Flying University was established. Parallel to other underground educational institutions, the JFU was created to serve as a semi-clandestine study group for both Jews and non-Jews interested in pursuing knowledge of Judaism, Jewish history, and Jewish culture (Gruber 2002). The institution, which attracted 60 to 80 people, had to disband under martial law in 1981. In the absence of Jewish educational institutions and in the face of a rather limited level of communication with the older generation, the generation of 1968, as they have been labeled (Irwin-Zarecka 1990; Melchior 1990), sought knowledge of "things Jewish" in books, primarily American publications, due to the lack of such literature in Polish at that time. For some, this underground activity resulted in an emancipation from a communist, atheist background, allowing them to move toward becoming involved and sometimes observant Jews (Gebert 1994; Grabski et al. 1997).

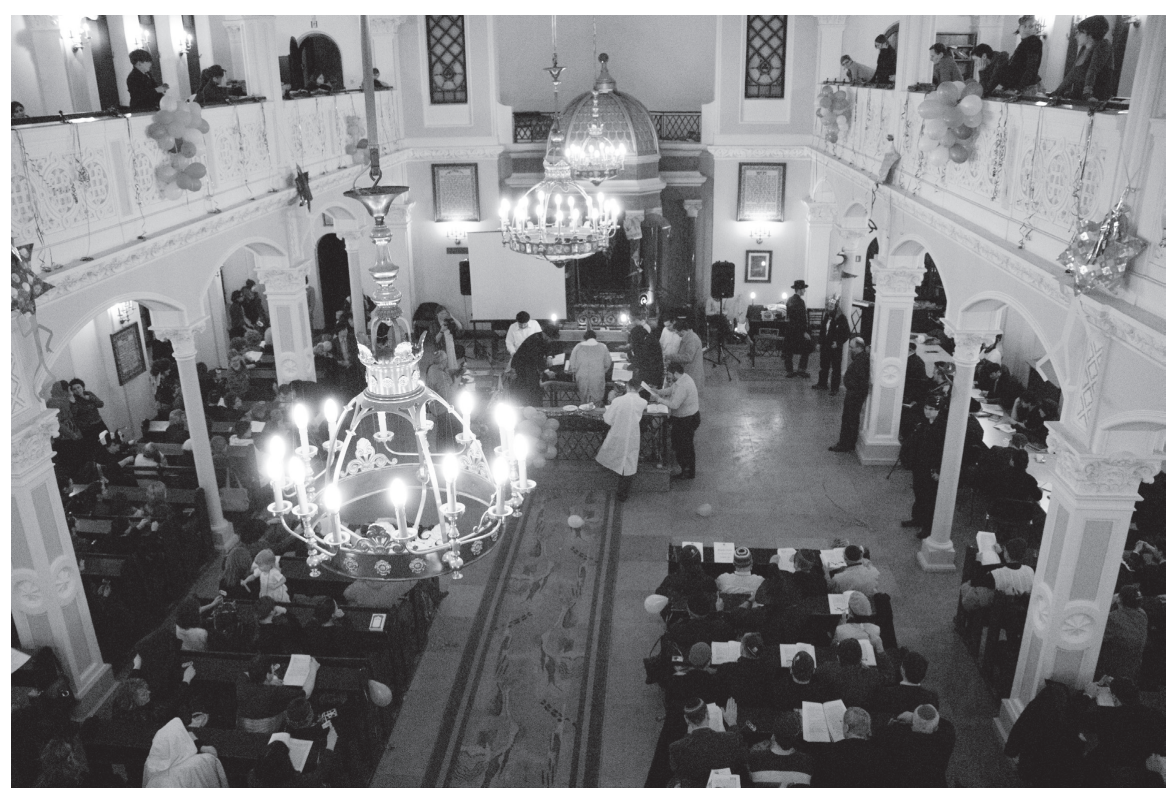

The Nozyk Synagogue in Warsaw, Holiday of Purim 2009 
The fall of the communist regime in 1989 prepared an entirely new ground for Jewish existence in Poland. Never after the political transition did official government policy discriminate against the Jews. In a form of vicious circle, however, popular anti-Jewish resentments took on a new logic, which identified political liberalism with a Jewish background (Gebert 1994). Aside from this ever-persisting popular antisemitic babble, there emerged a no less explicit tendency on the part of the government, but primarily the intellectual and artistic elites, to express active interest in Polish Jewish history and Polish-Jewish relations. Scholars and politicians began stressing the significance of Jewish culture in the Polish landscape throughout the ages. Members of the Christian intelligentsia became increasingly involved in JewishChristian religious dialogue, much of it owing to Pope John Paul II, who played a major role in Catholic-Jewish reconciliation in Poland and beyond. The growing interest in "things Jewish" continues to produce numerous Polish publications devoted to Jewish themes (Gruber 2002).

Immediately following the end of the war, the Jewish institutional network in Poland consisted of only two official institutions: the Jewish Central Committee in Poland, which in 1950 became the Social-Cultural Association of Jews in Poland, and the Union of Jewish Religious Congregations in Poland, temporarily renamed in the early post-war years the Union of Congregations of the Mosaic Faith (Schatz 1991). Both these establishments continue to exist today. The democratic changes with the fall of the communist regime in 1989 allowed for the development of the Jewish institutional network and for a considerable expansion of the scope of options available to individuals within that network.

We can speak of three generational groups in post-communist Poland (Grabski et al. 1997; Irwin-Zarecka 1990; Rosenson 1996). The pre-war generation of "old-timers" consists of people born before World War II, most of them Holocaust survivors. Discouraged from their Jewishness by the horrors of the Shoah and subsequently by the antisemitic riots and attacks in the early post-war years in Poland, especially the Kielce pogrom of July 1946, they were often enticed by and submissive to communist ideas (Gebert 1994). As was mentioned earlier, they often believed in the possibility of a secular, tolerant, international Poland as a project envisioned by some communist ideologists. Some Holocaust survivors had received a traditional Jewish education before the war, 
spoke Yiddish, and participated in Jewish ritual life, and some had been raised in relatively assimilated Polish homes, and their Jewishness was a cultural association rather than a religious one. After the war, some survivors decided to disguise their Jewish identification and similarly made no mention of it to their children. Others maintained ties with the socio-cultural association and/or with the local Jewish congregation.

The middle generation or the "68-ers" are generally associated with those Jews who left Poland as a result of the antisemitic purges of 1968 (for reference, see the documentary film The Peretzniks by Slawomir Grünberg, 2009). Today, the children of Holocaust survivors who remained in Poland are often labeled Second Generation. Whether they're called Generation '68, the March Generation (Wiszniewicz 2008), or simply the Second Generation, their Jewishness is largely defined by the experience of the 1968 expulsion. Those who remained in Poland and can be identified as Jews are generally people who chose to pursue a form of Jewish identity in early adulthood. Among them were those who had little or no awareness of their Jewish ancestry and who decided to learn "how to be Jewish" from foreign books and eventually became involved Jews like Konstanty Gebert and Stanislaw Krajewski, who became two of the leading Polish Jewish opinion makers and publicists in posttransition Poland. Many "68-ers" ended up joining anti-communist opposition and the "Solidarity" movement in the fight against the regime.

For the young generation of Polish Jews born after 1968, it is the year 1989, with the fall of the communist regime, that remains climactic (Gebert 1994; Gudonis 2001a; Krajewski 1997; Rosenson 1996). The shift in official policy and the spirit of democratic changes prepared the air for new attitudes toward the meaning of being Jewish and the sole idea of being anything other than Polish Catholic (Pinto 1996a,b). Whether the young representatives of this third post-Holocaust generation discovered their Jewish ancestry in their teens or had always been aware of it, it generally wasn't until the 1990s that they addressed that knowledge and initiated the pursuit of modes of Jewish affiliation. The younger representatives of this generation came of age in the first decade of the twenty-first century, and that is when they began their journey into Jewishness. The quest for forms of Jewishness enacted by "Generation '68" did not present itself as a case of direct inheritance (Gebert 1994). Similarly, the types of Jewish affiliation, which come to play in the discussion of the third generation, are scarcely indicative of 
adherence to the models endorsed by older generations. This generational discontinuity becomes even more striking given the fact that the parents of most of the young people I interviewed are not to be found among those who decided to embrace some form of Jewish affiliation in the period between the late 1960s and the early 1980s.

How many Jews are there in Poland today? It depends on who is asking who and who is defined as a Jew (Gebert 1994). Consequently, the answers range from a little over 1,000 to as many as 100,000. In 1996, Diana Pinto (1996b) estimated the number of members of the Polish Jewish community at 20,000. In 1999, the numbers were estimated at 5,000 to 15,000 (Sułek 1999). The Polish national census in 2002 included a question about national identification, and because Jews in Poland are in fact Polish nationals who, for the most part, identify as Poles, and the census did not include a question about religious affiliation, the number of Jews the census generated was 1,100. The fact that Jewish identification in Poland is not necessarily a national one is only one of the factors that make it difficult to estimate the number of Jews in today's Poland. Another problem is posed by the definition of Jewishness. The numbers vary greatly depending on whether we use the Orthodox halachic definition, that is, the definition according to the Jewish religious law, where being Jewish means being born from a Jewish mother, or the Israeli Law of Return definition, which grants the right to immigrate to Israel to every person with at least one Jewish grandparent. The third issue is that of mere awareness of Jewish ancestry-it is impossible to assess how many people in Poland remain unaware of their Jewish roots. Weinbaum (1998) stated that it is impossible to definitively speak of eight, ten, or even twenty-five thousand Jews in Poland. Gebert (1998) reported that the number of Jews in Poland remains between fifteen and forty thousand. In 2005, the Helsinki Federation for Human Rights estimated the Jewish minority in Poland at 7,000-15,000, living mostly in large cities (Warsaw, Wroclaw, Krakow, Lodz, Poznan, and Gdansk). In 2012, the official web site of the World Jewish Congress estimated the Jewish population of Poland at only 5,000, whereas the American Jewish Joint Distribution Committee estimated it at 25,000. Indeed, if we take into account all Poles with at least one Jewish grandparent and dare to include the ones who have yet to discover their Jewish roots, these modest numbers would need to be tripled, if not quadrupled. In 2011, when interviewed about Jewish life in Poland, the country's chief 
rabbi, Michael Schudrich, said, "Over the last 21 years, thousands of Poles have discovered that they have Jewish roots and nobody knows how many thousands they are." When asked how many Jews there are in Poland today, he answered, "Pick a number; double it. It is too small. I don't know, but tomorrow there will be more" (Zwalman Lerner 2011).

Most historical and sociological accounts of Jewish existence in Poland after World War II, which do not take into account the Jewish revival of the 1990s, give the impression that the Jewish story in Poland is over or about to end (Niezabitowska and Tomaszewski 1986; Vinecour and Fishman 1977; Ziemny 2000). Few publications have appeared since the 1990s, however, which highlight the cultural processes and the dynamic changes taking place in Jewish life in contemporary Poland (e.g., Cala and Datner-Spiewak 1997; Gebert 1994; Gudonis 2001a,b; Krajewski 2005; Mayer and Gelb 2002; Pragier 1992; Rosenson 1996; Weinbaum 1998). In Polish, the focus of the publications has been mostly on the socio-historical aspects. Grabski et al. (1997) offer a very general overview of Polish Jewry after the war, giving most attention to legal and demographic issues. Similarly, Datner and Melchior (1997) focus on demographic characteristics of contemporary Polish Jews as a minority group. Melchior's (1990) study of social identity of the representatives of the middle generation of Jews in Poland remains an important contribution. The issue of contemporary Jewish cultural performativity in Poland was raised in a number of significant publications (e.g., Gruber 2002; Schischa and Berenstein 2002). Jewish-Polish relations after the fall of the communist regime were addressed by both Polish and Western European authors (e.g., Krajewski 1997; Krajewski 2005; Michlic 2006; Orla-Bukowska and Cherry 2007; Pinto 1996a). Only a modest number of articles have been published since the 1990s dealing more specifically with the issue of identity of the young generation of Polish "new Jews," with their active pursuit of Jewish identity (e.g., Gudonis 2001a,b; Mayer and Gelb 2002; Pragier 1992; Rosenson 1996). There are a number of publications that appreciate the existence of the younger generation but do not actually address the topic in depth (Gebert 1994; Gruber 2002; Pinto 1996a; Ury 2000).

It is difficult to describe what democratic Poland is like. In 1984, British historian Norman Davies wrote, "[. . . Poland is the point where rival cultures and philosophies of our continent confront each other in the most acute form, where the tensions of the European drama are 
played out on the flesh and nerves of a large nation. Poland is not just a clod, or even a distant promontory; it is the heart of Europe" (Davies 1984, 463). Five years later, communism in Poland fell. In fact, some would say that the war ended in Poland in 1989. Ten years earlier, the Solidarity movement initiated the biggest revolution in the communist sector of Europe. Some argue that this secured the first and only successful uprising in Polish history (Surdykowski 2005), although many would see it as a rhetorical overstatement.

The participants in this study are people born in a country with a long and complex history of oppression. In other words, most of the participants in the study, including myself, were born in an authoritarian regime. Today, more than two decades into the new Poland, my interviewees represent an erratic generation that produces decadent malcontents (Melosik and Szkudlarek 1998; Świda-Ziemba 2005). They are too young to have had the opportunity to fight for capital F freedom, to have had the opportunity to make a difference on an international scale, and to have had that opportunity their fathers' generation had. In this study, I want to give an impression of the collective experience of the contemporary generation of young Polish adults. Of course, it is impossible to responsibly declare that all of my interviewees' fathers were freedom fighters and none of them supported the communist government, albeit passively.

It is important to note that during the 1980s, and perhaps beyond, associating oneself with the Catholic Church was tantamount to associating oneself-even if merely symbolically-with political opposition. Many Poles of Jewish origin found themselves fighting the regime, and for some this meant associating with the Catholic establishment. For those who "stood up," it meant to be on the side of the "good guys," and it meant to be part of a dangerous struggle for individuality, justice, and freedom. Because the regime represented anti-culture, those who fought against the regime used culture as a self-liberating, dignifying tool. There were of course those who supported the communist way, despite the growing disenchantment and although the communist ideal lost all of its charm in reality (Schatz 1991). It was often beneficial from a financial or practical point of view to conform with the regime, just as it might have been a safety precaution. However, those who chose to rebel against communist oppression were often extremely determined—at the symbolic level as well—to make every effort to defy the 
authorities, regardless of the dangers such actions could pose for them. As reported by several representatives of the third generation, some parents-regardless of their Jewish and often secular backgroundssaw fit to baptize their offspring purely as an act of defiance against the very aggressively anti-Catholic communist regime.

The identity stories of the representatives of the third generation are diverse. It is, however, significant that their Jewish experience is situated in a relatively new and still somewhat perturbed democracy. Allow me to remark that the general assessment among the young Polish Jewish adults is that they are "children of the revolution" who came of age in the newly liberated Poland. When we look at the young generation, we see that some remember communist times better than others, some remember their fathers' political imprisonments, and some remember only the empty shelves in grocery stores. No matter how dramatic or how prosaic the individual experiences might have been, as a generation they are children of dangerous or challenging times. They are adults, however, in times of relative social and political ease, where participating in culture is no longer part of the underground and where pronouncing their opinion is not likely to get them arrested.

Polish sociologist Świda-Ziemba (2005) speaks of "The New World" (Nowy swiat), which was established with the fall of the communist regime in 1989. What is important is that post-communist "New World" is the natural world for the young Polish adults of today; it is the world as they know it. Swida-Ziemba's research indicates that one of the characteristics of the generation of people who came of age in posttransition Poland is in fact a striking lack of generational awareness. This is expressed in individuals denying the fact that they belong to a certain historically and socially defined group. The young adults who participated in Świda-Ziemba's study talk about an endless multiplicity of possibilities, and they describe it in negative terms: disorienting, confusing, and empty. Along with general pessimistic attitudes comes the notion of freedom of choice: freedom to choose from among these multiple possibilities is described as an imprisoning emptiness. In other words, even freedom falls victim to cynicism. "Most of us are skeptical, cynical and ... miserable," says one of the participants in the study (Świda-Ziemba 2005, 23). Another person describes the condition in the following way, "We are a handicapped generation, because we don't know how to rebel. We can no longer fight for new civil liberties, because 
we already have complete civil freedom" (Świda-Ziemba 2005, 19).

Notwithstanding, it seems important to mention that perhaps especially during the past decade, a new context emerged wherein young Poles including-more significantly for this study-young Polish Jews do engage in a fight. The growing visibility of the Polish Lesbian, Gay, Bisexual, Transgender, and Queer (LGBT\&Q) community has led young Polish Jews to rather poignant expressions of a sense of solidarity and a willingness to join in the struggle for equal civil rights. In the past years, a growing number of Jews, often identified by an Israeli flag, joined the LGBT\&Q activists at demonstrations, protest marches, and equality parades organized every year in several large Polish cities. Common workshops are organized by the two communities, and more and more frequently they join each other's efforts in everyday protests or appeals against discrimination, racism, antisemitism, or homophobia. Many young people, among them Jews, in fact argue that-from a legal point of view-the situation of gays and lesbians in Poland is inferior to that of the Jews. For example, anti-Jewish speech is explicitly illegal in Poland, whereas homophobic hate speech is not, as of 2011. From a sociological point of view, comparing the situation of Jews and non-heteronormative persons in Poland since the fall of communism presents itself as a fascinating exercise which illuminates the complex processes of liberalization and pluralization of that part of Europe. In the Polish parliamentary elections of 2011, unexpectedly, the new political party of Janusz Palikot, who promised a liberal, anticlerical, pro-European, and pro-gay approach, was elected to the parliament having received votes primarily from young people, from the LGBT\&Q community, and-interestingly-from the country's Jews. As a result, the Polish Parliament welcomed its first openly gay male MP, Robert Biedroń, and its first transgender female MP, Anna Grodzka, who is currently the only transgender MP in the world.

In this book, I deal with a specific group of young adults in Poland, and their experience accounts for an exceptionally poignant phenomenon in that part of Europe, but that experience must surely be contextualized. It must be appreciated that young Polish adults who pursue a Jewish identity do so in the socio-historical context of a post-transition system and in the context of a country which engages in a very compelling debate not only on its Jewish past and present but also on its Catholic identity and its various persisting and ceasing xenophobias. 
Heterogeneity is described as one of the generational characteristics of the third post-war generation, or better yet the "non-generation." Once again, Świda-Ziemba's study reveals a peculiar paradox in the reports of the young adults. Namely, on the one hand, they talk about a unified picture of a generation as a sad victim of postmodern civilization, whereas on the other hand, the main features of this generation are described as heterogeneity, pluralism, and individualism. The general impression, as concluded by Świda-Ziemba (2005), is that we are looking at a group of people where everyone is on his or her own and everyone has to make it in this world of no authorities. All this is in many cases accompanied by a mythologized vision of the past and a certain nostalgia for the metaphysical, the existential, and the profound, which interestingly enough are perceived as characteristics of the past exclusively (Świda-Ziemba 2005). In a sense then, one of the things that the present condition has to offer to the third post-war generation is the possibility of turning to the past. 


\section{The Contemporary Polish Jewish CUltural Milieu}

Over THE PAST Two decades, thousands of Poles discovered that they have Jewish roots. Simultaneously, thousands of Poles discovered a strong interest in what we may generally label as Jewish culture. This means that the representatives of our third generation, who are embracing Jewish identity in contemporary Poland, are doing so in the peculiar reality of a Jewish cultural transformation happening in that part of Europe. The latter is subject to much controversy, which circles around the questions of authenticity and the complexities involved in defining Jewish culture. Nevertheless, today's Poland hosts probably more Jewish culture festivals than any other country in Europe, and the number of Jewish themes addressed in the arts and media is constantly growing, and this cannot be of no significance to the growing number of people who choose to identify as Jews.

In this study, I try to provide some insight into the mysterious world of the "unexpected generation" of Polish Jews, which began to emerge in the last decade of the twentieth century. At the same time, I address the incredible eruption of artistic campaigns and enterprises that popularize Jewish culture in Poland and create a new reality, which provokes a debate on both the real and the imaginary "return of the Jews."

For most Jews, Poland signifies more than just a country. A significant percentage of the world Jewish population, including approximately 75 percent of American Jews, trace their roots to Poland (Gruber 2002). Nevertheless, the image of Poland which remains the dominant one among Jews in other countries is that of a graveyard. Poland was home to the largest Jewish community in pre-war Europe, but it was also where the worst horrors of the Holocaust happened. Poland can never be "normal" for Jews. Not for the Jewish visitors, but perhaps not even for the local Jewish population. Nevertheless, the pursuit of some kind of "normalcy" by Jews living in Poland is an important and fascinating process. To allocate and establish oneself within a landscape 
as complex as the Polish one is one of the central challenges for Polish Jews and-arguably-especially so for the younger generation.

Some of this "Jewish roots mania" in Poland can be attributed to the work of the American-born Michael Schudrich, who began working in Poland in 1990 on behalf of the Ronald S. Lauder Foundation. Schudrich served as rabbi of Warsaw and Lodz since 2000, and was appointed Chief Rabbi of Poland in 2004. For the past two decades, Rabbi Schudrich has been one of the pillars of the Jewish revival in Poland, and he is partly responsible for the growing number of younger Polish Jews "coming out of the closet" in Poland. As a counselor for many young Poles who have just discovered their Jewish roots, Schudrich has been able to attract and accommodate some of those who are now the representatives of the third generation. Serving as an Orthodox rabbi, he necessarily is more likely to accommodate those who pursue an observant Jewish life, but his undeniable charisma causes many to "stick around" despite their lack of interest in religious practice. And as such, his role in the processes I discuss in this book is unquestionable. As is the role of such philanthropies like the Lauder Foundation and the Joint Distribution Committee whose support for Poland dates back to the 1980s, and more recently also organizations such as Shavei Israel. The impact of these foreign philanthropic organizations on the development of Jewish communal networks in Poland cannot be overestimated.

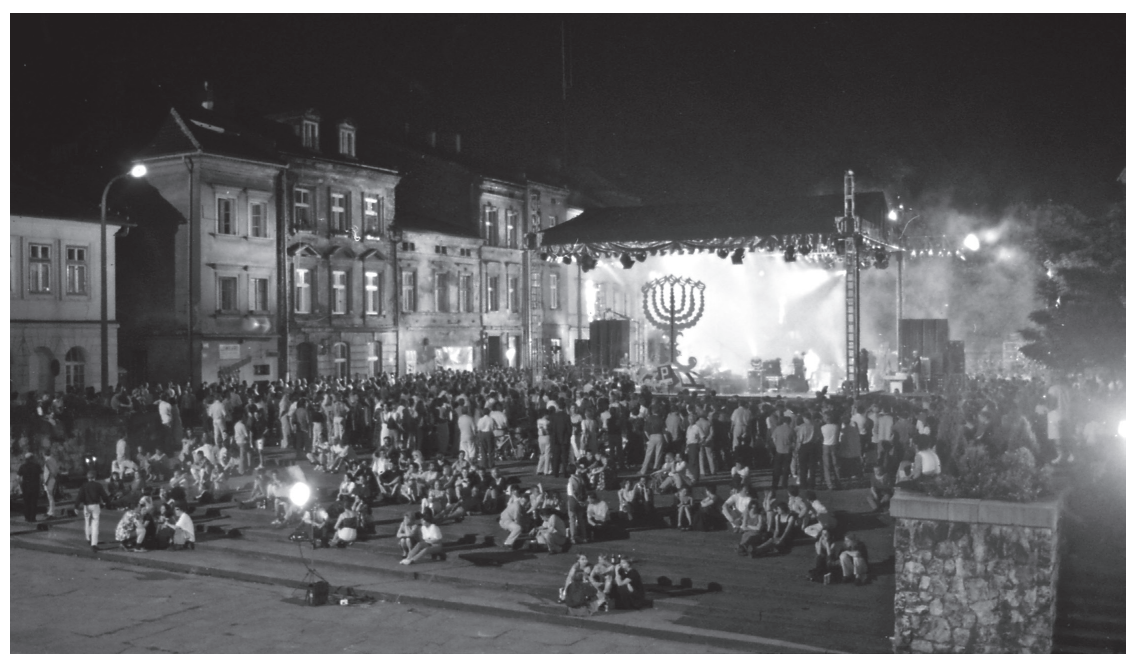

Jewish Culture Festival in Krakow 1999. 
For half a century between 1939 and 1989, being Jewish in Poland was not the most coveted identity. Since 1989, the number of Jews in Poland is actually growing, and deassimilation is at its best. Whereas for decades, many Jews in Poland pursued different forms of assimilation, since the 1990s assimilation is in reverse. Jews in Poland are "coming out of the closet." In a society where they had achieved a good level of "passing," of not being identified as Jews by others, they nevertheless "come out" as Jews publicly (see Stratton 2000).

Historians have repeatedly announced the end of Polish Jewry, and yet they-the unexpected "remnants"-now mostly in their 20s and 30s, take pride in calling themselves Polish Jews. The relationship between Poles and Jews has always been "special," whether good, bad, or just plain weird. This new generation is a generation of people who literally embody the relationship between Poles and Jews-they all epitomize Polish-Jewish relations. It is in this strange land, cursed and beloved by so many Jews, where Jews are cursed or beloved by antisemites or philosemites, respectively, that this generation of "neo-Semites" began to emerge in the last decade of the twentieth century, a generation of people who for the most part grew up as "regular" Polish Catholics but somehow ended up stumbling over their Jewish roots. Who would have thought that in this anguished land young people would pay so much attention to a heritage so many other young people have tried to escape throughout history? Why is it that the biggest insult for young Polish Jews is to be called "not real Jews"? What is even more remarkable is that all of this takes place in the context of a country which produces more Jewish festivals and art projects than any other country in Europe. Nearly every Polish city now holds a Jewish culture festival of some sort, and almost every day a Polish Jewish subject is brought up in the media. Polish-Israeli student exchanges take place every year, concerts of Jewish music happen all over the country, and a state-ofthe-art Museum of the History of Polish Jews is supposed to launch in Warsaw in 2013. This museum will be a product of cooperation between Jews and Poles, both creative and financial. Poland is considered one of the most pro-Israel countries in the European Union. Moreover, the fact that it does not cease to produce overwhelming numbers of Jewish art and culture projects creates an entirely new reality-an impressive "virtual Jewish world" (for a fascinating analysis of this phenomenon, 
see Gruber 2002). There isn't a week or perhaps a day in Poland without a "Jewish event" happening somewhere. A "Jewish renaissance in Poland" has made international news. The New York Times publishes articles about non-Jews reviving Poland's Jewish culture. So where, in all of this, are the Jews?

Perhaps the best representation of the "Jewish revival phenomenon" is the annual Jewish Culture Festival in Krakow-the largest Jewish culture festival in Europe. There, for one week, the organizers try to popularize the more attractive elements of Chasidic culture, with Klezmer music, traditional dance, and kosher-style food. Over the past twenty years, a great deal of attention has been paid in Krakow to rediscovering the city's "lost" Jewish culture and promoting it to a non-Jewish public (Gruber 2010). Numerous Jewish lecturers and performers are invited to the Festival every year, but the vast majority of the "consumers" are Poles with no Jewish roots. Crowds of people can be observed in Krakow every year dancing hypnotically in the streets of the former Jewish district. The revival of "some kind of Jewish culture" in Poland is unquestionable, but how alive and how "real" are the actual Jews?

Diana Pinto (1996a) points out that European Jews must make efforts to locate themselves within the landscape of Jewish cultural performativity, which is largely managed by non-Jews in Europe. In other words, they must decide whether to be part of it or to disassociate themselves from it, and whether to try to take advantage of it or avoid being affected by it. The strategy of the third generation regarding the Krakow Jewish Culture Festival is quite curious. Namely, they use it as a pretext to gather in Krakow from all over Poland and, rather than participate in the festival's program (aside from selected concerts by guest artists from abroad), organize their own alternative get-togethers and parties. They admit that the festival provides a special, somewhat surreal atmosphere, where for one week they are surrounded by Jewish or Jewish-like "things"-music, art, dance, food, books, posters, and so on. One of the institutions which helps organize some of the alternative activities for young Polish Jews during the time of the festival is Krakow's Jewish Community Center (JCC) run by the New York-born Jonathan Ornstein. The JCC organizes parties, lectures, and Shabbat meals during the festival, and the events are mostly run by Jews, for Jews. Non-Jews are welcome, as is the policy of the JCC on a regular basis. Since 2010, 
young Polish Jews have organized multiple lectures and workshops at the JCC which have become integrated in the Festival's program, and this is a good example of Jews becoming more involved in creating the Festival together with non-Jews. The Krakow JCC is the best representative of a growing tendency among young Polish Jews to become visible in the urban artistic and intellectual landscape and to try to engage the city's population in Jewish activity. "In terms of the way the Jewish community interacts with the non-Jewish community and the direction that things are going"-Ornstein told Ruth Ellen Gruber in an interview in 2011- "I think that there's never been a more optimistic time to be Jewish in Krakow than there is now. [. . .] The powerful message is that Judaism isn't just an idea, it's not just something that belongs to the Polish past, but there are Jews living here." What Jonathan believes, as noted by Gruber, is that "however small their numbers, Jews in Poland are not a separate, exotic entity but part and parcel of 21st century Polish society" (Gruber 2011).

Being an event created and originally organized by non-Jews and thus criticized by local and foreign Jews with regard to its authenticity, the Krakow Jewish Culture Festival cannot be denied a positive and good-humored quality, which attracts also the Jewish visitors. Such a relative balance of commercialism and quality content can no longer be found during the "Singer's Warsaw" Festival in the country's capital, which in turn is organized by the Jewish-run Shalom Foundation. The predominant style of Jewish culture presented at the festival is similar to that of Warsaw's Jewish Theater, which is, interestingly, run by the same family. How the Jewish Theater survived the removal of practically all Jewish institutions as part of the 1968 purge is no mystery to the better informed. Why the theater's audience, just like the majority of Singer's Warsaw Festival, is predominantly non-Jewish is even less mysterious. The theater's performances, featured in parts also during the festival, have been described as "A case of art trying, unsuccessfully, to imitate art, [. . .] moaning and swaying actors and actresses trying to ape Hasidim, [. . . ] non-Jewish actors in a Jewish theater, transmitting antisemitic stereotypes-in Yiddish-to the young generation of Poles!" (Hoffman 1992, 247 via Gruber 2002). Needless to say, the third generation of Polish Jews largely disassociate themselves from the Warsaw festival.

The Jewish Motifs Film Festival organized in Warsaw since 2003 
is another example of a venue which attracts many Poles and Poles of Jewish origin, and it has become a valued site in the landscape of contemporary Jewish cultural activity in Poland.

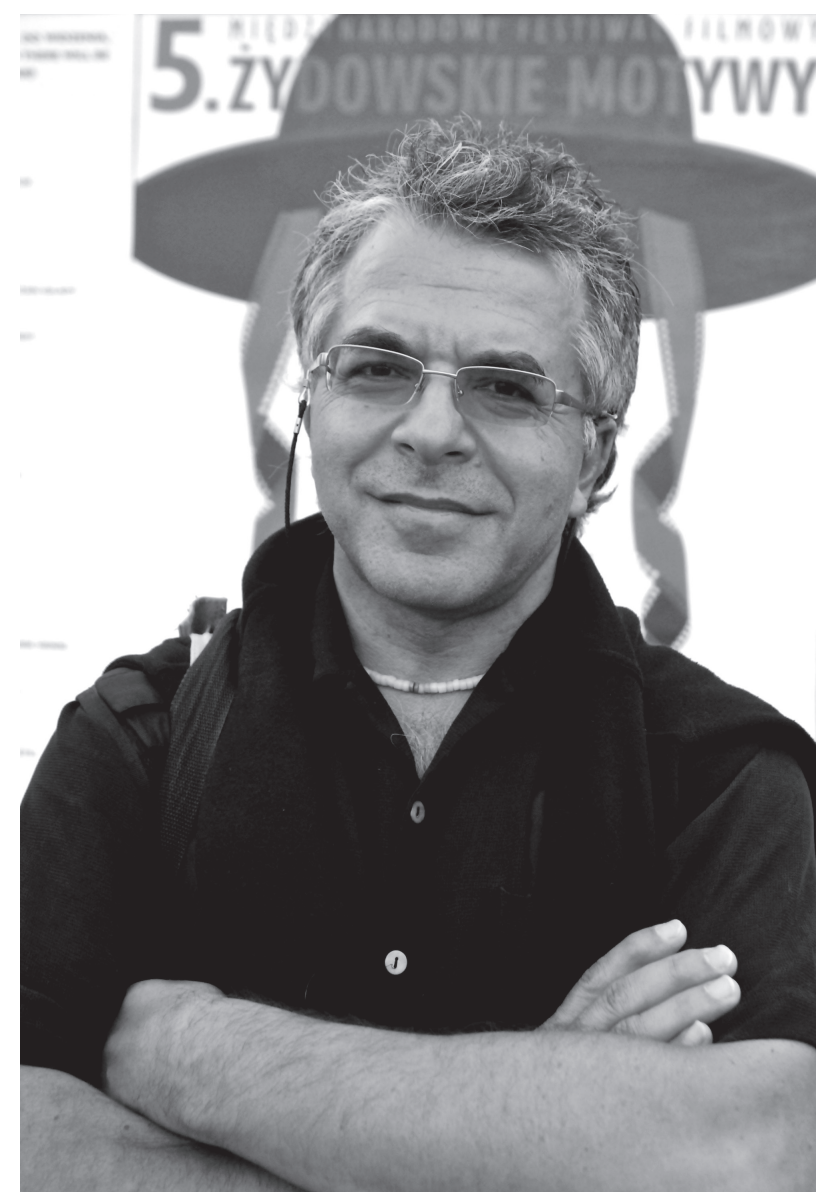

Filmmaker Slawomir Grünberg at the Jewish Motifs Film Festival in Warsaw in 2008.

Another successful enterprise worth mentioning is the Simcha Jewish Culture Festival organized in Wroclaw since 1999, which has over the years become a much respected and popular annual event in the "Polish Jewish calendar." Since 2008 Poland has its own Limmud Conferencenow the largest Jewish event in the country-where everyone is a student and anyone can be a teacher. Some 350 participants enrolled 
in 2008. Four years later, in 2012, Limmud Keshet Poland, which is organized by the American Jewish Joint Distribution Committee, is said to have hosted as many as 800 participants.

Another sphere of the Polish cultural milieu which affects local Jews, whether they want it to or not, is the growing number of Jewishthemed artistic enterprises and projects. Allow me to mention only a few. In 2007, Israeli multimedia artist Yael Bartana initiated the project "And Europe Will Be Stunned." The project consists primarily of three video installations and the establishment of a somewhat ambiguous movement known as the Jewish Renaissance Movement in Poland. The manifesto featured in this multimedia project calls for the return of 3,300,000 Jews to Poland-the land of their forefathers. The movement, with its appeals for more than three million Jews to come back to Poland, is an artistic invention. However, the scope of its influence has created a new reality-it is bewildering, to say the least, to both Poles and Jews. It has many debating, it has Polish antisemites protesting, and it has Polish philosemites excited. Polish Jews have yet to agree on how they feel about it. The eternal question "But is it good for the Jews?" comes to play also with regard to projects like "I miss you, Jew" ("Tesknię za Tobą, Żydzie"), which was launched by the Polish artist Rafal Betlejewski. Betlejewski appeals to the Polish public to send in any memorabilia and memories of Jews who once lived in places where they are no longer. The roots of this project go back to 2000, when Jan Tomasz Gross (2001), the Polish-born history professor at Princeton University, published Neighbors: The Destruction of the Jewish Community in Jedwabne, Poland. The book talks of the infamous massacre of Polish Jews in the village of Jedwabne, which was perpetrated by Poles and not by German occupiers, as had previously been assumed. The intellectual turmoil Gross caused in Poland cannot be overestimated. Finally the Polish public discourse opened itself, or was forced to open itself, to the most disturbing facts in Poland's anti-Jewish record, and while it stimulated antisemitism where it had been invisible, it brought about an invaluable reformation of national awareness at large. Polish intellectuals, some of them Jewish, others not, have written about the darkest chapters in Polish Jewish relations before Gross, but it was his uncompromising rhetoric and his compelling call for a new historiography that instigated a revolution in Poland (Orla-Bukowska and Cherry 2007).

It is perhaps this revolution that yields the many controversial art 
projects, which in different ways try to deal with the brutal confrontation with the most shameful chapters of Polish history. The idea of the project "I miss you, Jew" was simple. First, a list was compiled of cities and towns across Poland, which once had large Jewish populations. Betlejewski then visited those places and took photos of individuals and groups standing beside an empty chair with a skull cap on it as a sign of Jewish absence. A major event in Betlejewski's project was the 2010 public burning of a barn, meant to commemorate the Jedwabne massacre, in which Polish villagers burned their Jewish "neighbors" in a barn. The event caused much controversy and protests on the part of both Poles and Jews.

It is also in that same Poland that one can observe numerous vendors line up little clay, porcelain, and wooden figurines and memorabilia in their gift shops and market stands, among which the most valued souvenirs are tiny figurines shaped like "traditional" Jews. Large-nosed with sidelocks, accompanied by a fiddle, a book, or a cane, they are often also holding or standing by a Polish penny coin-the one grosz. Known in Polish folklore as good luck charms, relentlessly popular all over the country, sold by street vendors oblivious to the very unfortunate endorsement of notorious stereotypes, the "little Jews"-as they are called unconcernedly - crowd up next to little angels and dwarfs waiting for tourists and passers by. Once again, this "virtual Jewish presence" in Poland must be appreciated as a factor in the way Polish Jews see themselves and narrate their experience.

Another phenomenon, which is of significance especially for the younger generation of Jews in Poland, is Jewish tourism. As was mentioned before, the image of Poland as a massive Jewish graveyard shared by many foreign Jews necessarily shapes much of interaction they have with the representatives of the local Jewish community. Jewish American and Israeli visitors, most of whom come to Poland to see Nazi death camps, do not try to hide their astonishment when they realize that there are in fact Jews still living in Poland, including younger ones, and are similarly shocked at the fact that they actually choose to live in Poland rather than emigrate. Many are perhaps even more amazed at the fact that they meet young people who call themselves "Jews," although they did not grow up Jewish and do not have two Jewish parents. I address this issue further in my analysis of the interviews conducted with representatives of the third generation. 
Along with the visibility of Jewish "things"-festivals, publications, concerts, exhibitions, films, and grand projects such as the Museum of the History of Polish Jews, which is bound to make a big impact on Polish society, the visibility of actual Polish Jews also advances. This mosaic of Jewish-themed activity in Poland can create the impression that there is in fact a Jewish return taking place here-that Poland is undergoing a curious transformation and becoming-in many waysmore and more Jewish. The "invasion" of "Jewish things," the outspoken invitations voiced by artists for Jews to return to Poland, and the slow process of local Jews becoming more and more visible-all of this creates an almost surreal fantasy. Thus, the specific Polish cultural milieu, with all of its idiosyncrasies, necessarily conditions the processes of identity construction and the narratives of the third post-Holocaust generation of Jews in Poland. 